\title{
Square Wave Anodic Stripping Voltammetry for Simultaneous Determination of Trace Hg (II) and Tl(I) in Surface Water Samples Using $\mathrm{SnO}_{2} @$ MWCNTs Modified Glassy Carbon Electrode
}

\author{
Siyamthanda H. Mnyipika, Philiswa N. Nomngongo* \\ Department of Applied Chemistry, University of Johannesburg, P.O. Box 17011, Doornfontein, 2028, \\ South Africa \\ *E-mail: pnnomngongo@uj.ac.za; nomngongo@yahoo.com
}

doi: $10.20964 / 2017.06 .36$

Received: 7 November 2016 / Accepted: 14 April 2017 / Published: 12 May 2017

A rapid, simple and sensitive electrochemical sensor based on glassy carbon electrode modified with tin oxide nanoparticles @ multiwalled carbon nanotubes have been used for determination of trace $\mathrm{Hg}(\mathrm{II})$ and $\mathrm{Tl}(\mathrm{I})$ using the square wave anodic stripping voltammetric (SWASV) technique. Under optimized condition, the limit of detection and quantification ranged from $0.9-1.2 \mathrm{ng} \mathrm{L}^{-1}$ and 3.3-4.0 $\mathrm{ng} \mathrm{L}{ }^{-1}$, respectively. The inter-day $(\mathrm{n}=10)$ and intra-day $(\mathrm{n}=7)$ precisions expressed in relative standard deviations at $50 \mu \mathrm{g} \mathrm{L} \mathrm{L}^{-1}$ of $\mathrm{Hg}(\mathrm{II})$ and $\mathrm{Tl}(\mathrm{I})$ ranged from 2.1-3.5 and 3.0-4.3\%, respectively. The GCE/SnO ${ }_{2} @ M W C N T s$ was applied for the determination of the target trace elements in thirteen surface water samples. The accuracy of analytical results obtained using the developed electrochemical sensor was comparable to those obtained by the ICP-MS.

Keywords: Tin dioxide@ multiwall carbon nanotubes; thallium (I); mercury (II), square wave anodic stripping voltammetry, surface water

\section{$\underline{\text { FULL TEXT }}$}

(C) 2017 The Authors. Published by ESG (www.electrochemsci.org). This article is an open access article distributed under the terms and conditions of the Creative Commons Attribution license (http://creativecommons.org/licenses/by/4.0/). 